\title{
Hansschlegelia zhihuaiae sp. nov., isolated from a polluted farmland soil
}

\author{
Ya Wen, ${ }^{1} \dagger$ Xing Huang, ${ }^{1} \dagger$ Yu Zhou, ${ }^{2}$ Oing Hong ${ }^{1}$ and Shunpeng $\mathrm{Li}^{1}$ \\ ${ }^{1}$ Key Laboratory of Microbiological Engineering of Agricultural Environment, Ministry of Agriculture, \\ Life Sciences College of Nanjing Agricultural University, Nanjing, Jiangsu 210095, PR China \\ ${ }^{2}$ Institute of Quality and Standard for Agricultural Products, Zhejiang Academy of Agricultural \\ Sciences (ZAAS), Hangzhou, Zhejiang 310021, PR China
}

Correspondence

Shunpeng Li

Isp@njau.edu.cn

\begin{abstract}
A novel Gram-negative, aerobic, coccoid-shaped strain designated $S 113^{\top}$ was isolated from a polluted-soil sample collected in Jiangsu Province, China. A polyphasic taxonomic study including phylogenetic analysis based on the 16S rRNA gene sequence and determination of phenotypic characteristics was performed on the new isolate. The highest 16S rRNA gene sequence similarity was $96.8 \%$, with Hansschlegelia plantiphila $\mathrm{S}_{1}{ }^{\top}$. The predominant respiratory quinone

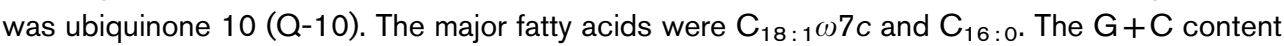
of the DNA was about 65.7 mol\%. DNA-DNA hybridization experiments showed $44.9 \%$ relatedness for strain $S 113^{\top}$ with its closest relative, $H$. plantiphila NCIMB $14035^{\top}$. The dominant phospholipids were diphosphatidylglycerol, phosphatidylglycerol, phosphatidylethanolamine, phosphatidylmonomethylethanolamine and phosphatidylcholine. The results of our polyphasic taxonomic analysis indicate that strain $S 113^{\top}$ represents a novel species within the genus Hansschlegelia, for which the name Hansschlegelia zhihuaiae sp. nov. is proposed. The type strain is $\mathrm{S} 113^{\top}\left(=\mathrm{DSM} 18984^{\top}=\right.$ CCTCC AB $206143^{\top}=$ KCTC $\left.12880^{\top}\right)$.
\end{abstract}

The family Methylocystaceae was proposed by Bowman $(2005,2006)$ to harbour the group II methanotrophs, and the type genus is Methylocystis (Bowman et al., 1993). At the time of writing, the family contains six established genera: Albibacter, Methylocystis, Methylopila, Methylosinus, Pleomorphomonas and Terasakiella. Most members of the family have been isolated from soil, groundwater or other complex environmental samples (Bowman et al., 1993; Doronina et al., 1998, 2001; Satomi et al., 2002; Dedysh et al., 2007). The genus Hansschlegelia, which was described by Ivanova et al. (2007), is also a member of family Methylocystaceae; the name has recently been validly published (Ivanova et al., 2010). Many methanotrophic bacteria represent critical links in the global carbon cycle, act as $\mathrm{N}_{2}$ fixers, degrade a wide array of organic contaminants and display many enzymic functions (Gulledge et al., 2001). 16S rRNA gene sequence analysis has shown that members of the family Methylocystaceae are able to utilize methanol as a carbon source and exhibit the serine or ribulose-bisphosphate pathway for formaldehyde assimilation (Gallego et al., 2005).

TThese authors contributed equally to this work.

The GenBank/EMBL/DDBJ accession number for the 16S rRNA gene sequence of strain $\mathrm{S} 113^{\top}$ is D0916067.

A supplementary table and a supplementary figure are available with the online version of this paper.
In the course of an investigation of the bacterial community in a farmland soil that was seriously contaminated by sulfonylurea herbicides in Jiangsu province, China, strain $\mathrm{S} 113^{\mathrm{T}}$ was isolated and subjected to a polyphasic taxonomic analysis. We propose here that it represents a novel species in the genus Hansschlegelia.

Strain S $113^{\mathrm{T}}$ was isolated using the medium and methods described by Huang et al. (2007) from a sample of polluted farmland soil. The pure culture was preserved in a $25 \%$ $(\mathrm{v} / \mathrm{v})$ glycerol solution in distilled water at $-80{ }^{\circ} \mathrm{C}$.

The morphological characteristics of the strain were observed by transmission electron microscopy (model $\mathrm{H}$ 7650; Hitachi) after incubation for 3 days at $30{ }^{\circ} \mathrm{C}$ on YTC agar $\left(0.3 \%\right.$ yeast, $0.5 \%$ tryptone and $\left.0.001 \% \mathrm{CaCl}_{2}\right)$. Electron microscopy preparations were performed as described by Yoon et al. (2003). Growth was tested in liquid mineral medium $\mathrm{K}$ in which methanol or methylamine was added at a concentration of $0.5 \%(\mathrm{v} / \mathrm{v})$ and formaldehyde was added at $0.05 \%(\mathrm{v} / \mathrm{v})$, as described by Doronina et al. (1998). The method of Yamaguchi \& Yokoe (2000) was followed to determine acid production from carbohydrates. Utilization of sole carbon sources was performed as described by Zhou et al. (2007). Growth was tested at $5,10,25,30,35,37$ and $40{ }^{\circ} \mathrm{C}$ in YTC broth and $\mathrm{pH}$ tolerance was tested using modified YTC broth adjusted to $\mathrm{pH} 3.0,5.0,6.0,6.5,7.0,7.5,8.0$ and 9.0. Antibiotic susceptibility was examined by placing antibiotic 
discs on YTC plates as described by Zhou et al. (2007). Gram-staining and other physiological characteristics were assessed according to the methods of Doronina et al. (1998) and Gerhardt et al. (1994). API 20NE strips (bioMérieux) were used to investigate additional biochemical features.

Biomass for molecular systematic and chemotaxonomic tests was obtained using YTC broth or methanol medium $\mathrm{K}$ by incubation at $30{ }^{\circ} \mathrm{C}$ for 10 days in shaking flasks (about 180 r.p.m.). Respiratory quinones were extracted from lyophilized cells and the sample was purified and analysed by HPLC using the procedures reported by $\mathrm{Hu}$ et al. (2001). Cellular fatty acid composition was determined as described by Sasser (1990) using the Microbial Identification System (MIDI, Inc.). Polar lipid analyses were carried out as described by Minnikin et al. (1984). The predominant respiratory quinone of strain $S$ $113^{\mathrm{T}}$ was ubiquinone $10(\mathrm{Q}-10)$. The major fatty acids were $\mathrm{C}_{18: 1} \omega 7 c(77 \%)$ and $\mathrm{C}_{16: 0}(14.3 \%)$; the detailed fatty acid profile is displayed in Supplementary Table S1, available in IJSEM Online. The dominant phospholipids were diphosphatidylglycerol, phosphatidylglycerol, phosphatidylethanolamine, phosphatidylmonomethylethanolamine and phosphatidylcholine.

Genomic DNA for base composition analysis was prepared following the procedure of Marmur (1961). DNA G+C content was determined by reversed-phase HPLC according to Tamaoka \& Komagata (1984); the DNA G+C content of S $113^{\mathrm{T}}$ was $65.7 \mathrm{~mol} \%$. DNA-DNA relatedness was determined by the initial renaturation rate method in $2 \times$ SSC (De Ley, 1970). Genomic DNA-DNA relatedness between $\mathrm{S} 113^{\mathrm{T}}$ and Hansschlegelia plantiphila NCIMB $14035^{\mathrm{T}}$ was $44.9 \%$, which is below the value of $70 \%$ recommended for species definition (Wayne et al., 1987).
PCR amplification of the 16S rRNA gene was performed as described by Xu et al. (2003). The 16S rRNA gene sequence was aligned manually with reference sequences retrieved from the GenBank database following BLAST searches. Phylogenetic trees were reconstructed using the software package MEGA version 3.1 (Kumar et al., 2004) after multiple alignment of the data by CLUSTAL_X (Thompson et al., 1997). Distances (distance options according to Kimura's two-parameter model; Kimura, 1980, 1983) and clustering were based on the neighbour-joining and maximum-parsimony methods (Saitou \& Nei, 1987). Bootstrap analysis was applied to evaluate the topology of the neighbour-joining tree by performing 1000 resamplings (Felsenstein, 1985).

The almost-complete 16S rRNA gene sequence (1444 bp) of strain $\mathrm{S} 113^{\mathrm{T}}$ was determined. The neighbour-joining phylogenetic tree (Fig. 1) reconstructed from 16S rRNA gene sequences showed clearly that strain $\mathrm{S} 113^{\mathrm{T}}$ belongs to the genus Hansschlegelia; the strain showed $96.8 \% 16 \mathrm{~S}$ rRNA gene sequence similarity value to its closest neighbour, $H$. plantiphila $\mathrm{S}_{1}{ }^{\mathrm{T}}$.

Phylogenetic analysis, genomic DNA-DNA hybridization and chemotaxonomy support the inclusion of the new isolate as a member of genus Hansschlegelia. Strain S $113^{\mathrm{T}}$ can be differentiated easily from the only species currently classified in this genus, $H$. plantiphila, by some important phenotypic properties such as motility, catalase activity, $\mathrm{H}_{2} \mathrm{~S}$ production and $\mathrm{NaCl}$ tolerance (Table 1 ). The type strains of the two species also displayed significant differences in fatty acid and polar lipid compositions (Table 1 and Supplementary Table S1). On the basis of the phylogenetic and chemotaxonomic evidence together with the phenotypic characteristics presented in this study, the newly isolated strain $\mathrm{S} 113^{\mathrm{T}}$ is assigned to a novel species

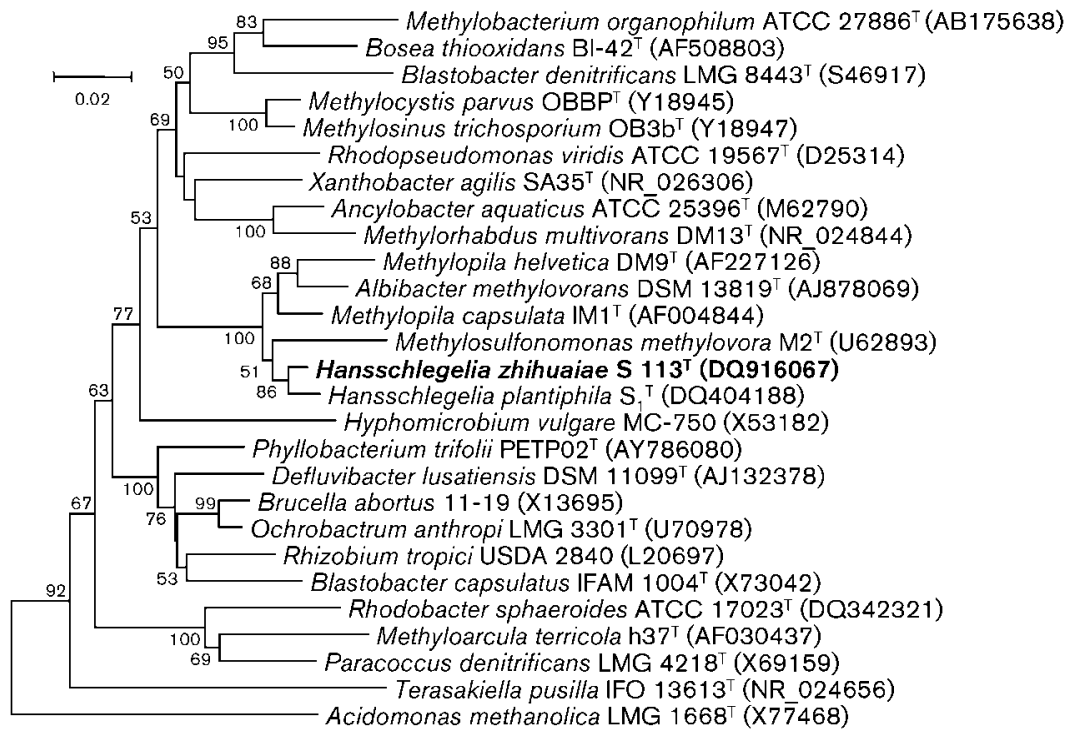

Fig. 1. Neighbour-joining phylogenetic tree based on 16S rRNA gene sequences of strain $S 113^{\top}$ compared with members of representative genera of the family Methylocystaceae and some non-methylotrophs in the phylum Proteobacteria. Numbers at nodes indicate percentage bootstrap values from 1000 resamplings; values $\geqslant 50 \%$ are shown. Bar, 0.02 substitutions per nucleotide position. The maximum-parsimony tree showed essentially the same topology (not shown). 
Table 1. Phenotypic characteristics that differentiate strain $S 113^{\top}$ from its phylogenetically closest neighbour, $H$. plantiphila NCIMB $14035^{\top}$

+ , Positive; -, negative; $(+$ ), weakly positive. Data for major fatty acids, phospholipids, DNA G + C content and $\mathrm{NaCl}$ tolerance of $H$. plantiphila $\mathrm{S}_{1}{ }^{\mathrm{T}}$ were taken from Ivanova et al. (2007); other data were obtained in this study.

\begin{tabular}{|c|c|c|}
\hline Characteristic & Strain $S 113^{T}$ & H. plantiphila NCIMB $14035^{\mathrm{T}}$ \\
\hline Cell morphology & Coccoid & Short rod \\
\hline Flagella & + & - \\
\hline $\mathrm{NaCl}$ tolerance & $<0.5 \%$ & $<2 \%$ \\
\hline $\mathrm{H}_{2} \mathrm{~S}$ production & - & + \\
\hline Catalase & - & + \\
\hline Oxidase & $(+)$ & + \\
\hline Urease & $(+)$ & + \\
\hline \multicolumn{3}{|l|}{ Carbon source utilization } \\
\hline Succinate & - & $(+)$ \\
\hline Formaldehyde & - & + \\
\hline Methylamine & - & + \\
\hline Starch & + & - \\
\hline Pyruvate & + & - \\
\hline Major fatty acids & $\mathrm{C}_{18: 1} \omega 7 c, \mathrm{C}_{16: 0}$ & $\mathrm{C}_{16: 0}, \mathrm{C}_{19: 0}$ cyclo, $\mathrm{C}_{18: 1} \omega 7 c$ \\
\hline Dominant phospholipids* & DPG, PC, PE, PME, PG & $\mathrm{DPG}, \mathrm{PC}, \mathrm{PE}$ \\
\hline DNA G $+C$ content $(\mathrm{mol} \%)$ & 65.7 & 68.5 \\
\hline
\end{tabular}

${ }^{*}$ DPG, Diphosphatidylglycerol; PC, phosphatidylcholine; PE, phosphatidylethanolamine; PG, phosphatidylglycerol; PME, phosphatidylmonomethylethanolamine.

in the genus Hansschlegelia, for which the name Hansschlegelia zhihuaiae sp. nov. is proposed.

\section{Description of Hansschlegelia zhihuaiae sp. nov.}

Hansschlegelia zhihuaiae [zhi.hua.i'ae. N.L. fem. gen. n. zhihuaiae named after Zhihua Wu (1935-2001), a Chinese pedologist who devoted herself to the study of soil biology].

Cells are Gram-negative, non-spore-forming, aerobic coccoids $(0.6-0.9 \times 1.0-1.3 \mu \mathrm{m})$ (Supplementary Fig. S1). Colonies are circular and white on YTC agar, 1.0-2.0 mm in diameter after 3 days of cultivation at $30{ }^{\circ} \mathrm{C}$. Moderately sensitive to $\mathrm{NaCl}(<0.5 \%)$. Shows good growth in liquid mineral medium $\mathrm{K}$ with $0.5 \%(\mathrm{v} / \mathrm{v})$ methanol but not with formaldehyde or methylamine. Good growth occurs at 25$30{ }^{\circ} \mathrm{C}$ and at $\mathrm{pH} 6.5-7.5$, but not above $\mathrm{pH} 9.0$ or below $\mathrm{pH}$ 6.0. Starch is hydrolysed; casein, cellulose, DNA, gelatin and Tween 80 are not hydrolysed. Acid is produced from adonitol, melezitose and sucrose, but not from Darabinose, cellobiose, dulcitol, D-fructose, L-fucose, Dgalactose, D-glucose, inositol, lactose, maltose, D-mannitol, melibiose, raffinose, L-rhamnose, D-ribose, L-sorbose, Dsorbitol, trehalose or D-xylose. D-Arabinose, glucosamine, pyruvate and starch are utilized. N-Acetylglucosamine, acetate, aesculin, cellobiose, dulcitol, dextrin, D-erythrose, D-fructose, D-galactose, gelatin, D-glucose, inulin, inositol, lactose, D-mannose, maltose, melibiose, D-mannitol, mucic acid, malonate, raffinose, D-ribose, ribulose, D-sorbitol, Dsorbose, salicin, trehalose, Tween 80 , turanose, tartrate, xylitol and D-xylose are not utilized. Weak oxidase and urease activities are present. Arginine decarboxylase, arginine dihydrolase, catalase, DNase, $\beta$-galactosidase, lysine decarboxylase, methyl $\alpha$-D-glucosidase, ornithine decarboxylase and phenylalanine decarboxylase activities are absent. $\mathrm{H}_{2} \mathrm{~S}$ is not produced (triple sugar-iron reaction). Reduces nitrates to nitrites. Methyl red and Voges-Proskauer tests are negative. KCN $(0.0075 \%)$ is not tolerated. Susceptible to ( $\mu \mathrm{g}$ per disc unless indicated) chloramphenicol (30), doxycycline (30), gentamicin (10), kanamycin (30), neomycin (30), polymixin B (100 U), rifampicin (5), streptomycin (10) and tetracycline (30); resistant to ampicillin (10), erythromycin (15), lincomycin (15), penicillin $\mathrm{G}(10 \mathrm{U}$ ) and vancomycin (30). The major fatty acids are $\mathrm{C}_{18: 1} \omega 7 c$ and $\mathrm{C}_{16: 0}$. The dominant phospholipids are diphosphatidylglycerol, phosphatidylcholine, phosphatidylethanolamine, phosphatidylmonomethylethanolamine and phosphatidylglycerol. The DNA $\mathrm{G}+\mathrm{C}$ content of the type strain is $65.7 \mathrm{~mol} \%$ (HPLC).

The type strain, $\mathrm{S} 113^{\mathrm{T}}\left(=\mathrm{DSM} 18984^{\mathrm{T}}=\right.$ CCTCC $\mathrm{AB}$ $206143^{\mathrm{T}}=$ KCTC $12880^{\mathrm{T}}$ ), was isolated from the surface layer of a polluted farmland soil from Jiangsu province, China.

\section{Acknowledgements}

The authors are grateful to the Identification Service of the DSMZ (Braunschweig, Germany) and Dr B. J. Tindall (DSMZ) for polar lipid analyses. This work was supported by grants from the National Natural Science Foundation of China (30830001, 30900044), the Fund for the Doctoral Program of Higher Education (2009009 
7120031) and the Social Development Program Fund of Jiangsu Province (BS2007056).

\section{References}

Bowman, J. P. (2005). Family V. Methylocystaceae fam. nov. In Bergey's Manual of Systematic Bacteriology, 2nd edn, vol. 2C, pp. 411413. Edited by D. J. Brenner, N. R. Krieg, J. T. Staley \& G. M. Garrity. New York: Springer.

Bowman, J. P. (2006). Methylocystaceae fam. nov. In List of New Names and New Combinations Previously Effectively, but not Validly, Published. Validation List no. 107. Int J Syst Evol Microbiol 56, 1-6.

Bowman, J. P., Sly, L. I., Nichols, P. D. \& Hayward, A. C. (1993). Revised taxonomy of the methanotrophs: description of Methylobacter gen. nov., emendation of Methylococcus, validation of Methylosinus and Methylocystis species, and a proposal that the family Methylococcaceae includes only the group I methanotrophs. Int J Syst Bacteriol 43, 735-753.

De Ley, J. (1970). Reexamination of the association between melting point, buoyant density, and chemical base composition of deoxyribonucleic acid. J Bacteriol 101, 738-754.

Dedysh, S. N., Belova, S. E., Bodelier, P. L., Smirnova, K. V., Khmelenina, V. N., Chidthaisong, A., Trotsenko, Y. A., Liesack, W. \& Dunfield, P. F. (2007). Methylocystis heyeri sp. nov., a novel type II methanotrophic bacterium possessing 'signature' fatty acids of type I methanotrophs. Int J Syst Evol Microbiol 57, 472-479.

Doronina, N. V., Trotsenko, Y. A., Krausova, V. I., Boulygina, E. S. \& Tourova, T. P. (1998). Methylopila capsulata gen. nov., sp. nov., a novel non-pigmented aerobic facultatively methylotrophic bacterium. Int J Syst Bacteriol 48, 1313-1321.

Doronina, N. V., Trotsenko, Y. A., Tourova, T. P., Kuznetsov, B. B. \& Leisinger, T. (2001). Albibacter methylovorans gen. nov., sp. nov., a novel aerobic, facultatively autotrophic and methylotrophic bacterium that utilizes dichloromethane. Int J Syst Evol Microbiol 51, 1051-1058.

Felsenstein, J. (1985). Conference limits on phylogenies: an approach using the bootstrap. Evolution 39, 783-789.

Gallego, V., García, M. T. \& Ventosa, A. (2005). Methylobacterium hispanicum sp. nov. and Methylobacterium aquaticum sp. nov. isolated from drinking water. Int J Syst Evol Microbiol 55, 281-287.

Gerhardt, P., Murray, R. G. E., Wood, W. A. \& Krieg, N. R. (1994). Methods for General Molecular Bacteriology. Washington, DC: American Society for Microbiology.

Gulledge, J., Ahmad, A., Steudler, P. A., Pomerantz, W. J. \& Cavanaugh, C. M. (2001). Family- and genus-level 16S rRNA-targeted oligonucleotide probes for ecological studies of methanotrophic bacteria. Appl Environ Microbiol 67, 4726-4733.

Hu, H. Y., Lim, B.-R., Goto, N. \& Fujie, K. (2001). Analytical precision and repeatability of respiratory quinones for quantitative study of microbial community structure in environmental samples. J Microbiol Methods 47, 17-24.

Huang, X., He, J., Sun, J., Pan, J., Sun, X. \& Li, S. (2007). Isolation and characterization of a metsulfuron-methyl degrading bacterium Methylopila sp. S113. Int Biodeterior Biodegradation 60, 152-158.

Ivanova, E., Doronina, N. \& Trotsenko, Y. (2007). Hansschlegelia plantiphila gen. nov. sp. nov., a new aerobic restricted facultative methylotrophic bacterium associated with plants. Syst Appl Microbiol 30, 444-452.
Ivanova, E., Doronina, N. \& Trotsenko, Y. (2010). Hansschlegelia plantiphila gen. nov., sp. nov. In List of New Names and New Combinations Previously Effectively, but not Validly, Published. Validation List no. 133. Int J Syst Evol Microbiol 60, 1009-1010.

Kimura, M. (1980). A simple method for estimating evolutionary rates of base substitutions through comparative studies of nucleotide sequences. J Mol Evol 16, 111-120.

Kimura, M. (1983). The Neutral Theory of Molecular Evolution. Cambridge: Cambridge University Press.

Kumar, S., Tamura, K. \& Nei, M. (2004). MEGA3: integrated software for molecular evolutionary genetics analysis and sequence alignment. Brief Bioinform 5, 150-163.

Marmur, J. (1961). A procedure for the isolation of deoxyribonucleic acid from microorganisms. J Mol Biol 3, 208-218.

Minnikin, D. E., O'Donnell, A. G., Goodfellow, M., Alderson, G., Athalye, M., Schaal, A. \& Parlett, J.-H. (1984). An integrated procedure for the extraction of bacterial isoprenoid quinones and polar lipids. J Microbiol Methods 2, 233-241.

Saitou, N. \& Nei, M. (1987). The neighbor-joining method: a new method for reconstructing phylogenetic trees. Mol Biol Evol 4, 406425.

Sasser, M. (1990). Identification of bacteria by gas chromatography of cellular fatty acids. USFCC Newsl 20, 16.

Satomi, M., Kimura, B., Hamada, T., Harayama, S. \& Fujii, T. (2002). Phylogenetic study of the genus Oceanospirillum based on 16S rRNA and gyrB genes: emended description of the genus Oceanospirillum, description of Pseudospirillum gen. nov., Oceanobacter gen. nov. and Terasakiella gen. nov. and transfer of Oceanospirillum jannaschii and Pseudomonas stanieri to Marinobacterium as Marinobacterium jannaschii comb. nov. and Marinobacterium stanieri comb. nov. Int J Syst Evol Microbiol 52, 739-747.

Tamaoka, J. \& Komagata, K. (1984). Determination of DNA base composition by reversed-phase high-performance liquid chromatography. FEMS Microbiol Lett 25, 125-128.

Thompson, J. D., Gibson, T. J., Plewniak, F., Jeanmougin, F. \& Higgins, D. G. (1997). The CLUSTAL_X windows interface: flexible strategies for multiple sequence alignment aided by quality analysis tools. Nucleic Acids Res 25, 4876-4882.

Wayne, L. G., Brenner, D. J., Colwell, R. R., Grimont, P. A. D., Kandler, O., Krichevsky, M. I., Moore, L. H., Moore, W. E. C., Murray, R. G. E. \& other authors (1987). International Committee on Systematic Bacteriology. Report of the ad hoc committee on reconciliation of approaches to bacterial systematics. Int J Syst Bacteriol 37, 463-464.

Xu, P., Li, W.-J., Xu, L.-H. \& Jiang, C.-L. (2003). A microwave-based method for genomic DNA extraction from actinomycetes. Microbiology (Beijing) 30, 82-84 (in Chinese).

Yamaguchi, S. \& Yokoe, M. (2000). A novel protein-deamidating enzyme from Chryseobacterium proteolyticum sp. nov., a newly isolated bacterium from soil. Appl Environ Microbiol 66, 3337-3343.

Yoon, J. H., Kim, I. G., Kang, K. H., Oh, T. K. \& Park, Y. H. (2003). Bacillus marisflavi sp. nov. and Bacillus aquimaris sp. nov., isolated from sea water of a tidal flat of the Yellow Sea in Korea. Int J Syst Evol Microbiol 53, 1297-1303.

Zhou, Y., Dong, J., Wang, X., Huang, X., Zhang, K. Y., Zhang, Y. Q., Guo, Y. F., Lai, R. \& Li, W.-J. (2007). Chryseobacterium flavum sp. nov., isolated from polluted soil. Int J Syst Evol Microbiol 57, 17651769. 